Canadian University Music Review

Canadian University Music Review

Revue de musique des universités canadiennes

\title{
"I See the Fretboard in Diagrams": An Examination of the Improvisatory Style of Herbert Lawrence "Sonny" Greenwich
}

\section{Andrew Scott}

Volume 24, numéro 1, 2003

URI : https://id.erudit.org/iderudit/1014671ar

DOI : https://doi.org/10.7202/1014671ar

Aller au sommaire du numéro

\section{Éditeur(s)}

Canadian University Music Society / Société de musique des universités canadiennes

ISSN

0710-0353 (imprimé)

2291-2436 (numérique)

Découvrir la revue

Citer cet article

Scott, A. (2003). "I See the Fretboard in Diagrams": An Examination of the Improvisatory Style of Herbert Lawrence "Sonny" Greenwich. Canadian University Music Review / Revue de musique des universités canadiennes, 24(1), 62-78. https://doi.org/10.7202/1014671ar
Résumé de l'article

L'auteur se penche sur le style d'improvisation du musicien de jazz Herbert Lawrence « Sonny » Greenwich. Si de nombreuses sources extra-musicales nous renseignent sur les prestations du guitariste, les tableaux cubistes de Paul Klee s'avèrent particulièrement significatifs. À l'aide de transcriptions, d'analyses et d'entrevues, l'auteur démontre que les " diagrammes » des positions sur le manche - qui proviendraient de Klee, selon Greenwich jouent trois rôles. D'abord, ils fournissent à Greenwich une manière personnelle d'approcher son art. Ensuite, ils offrent une stratégie convenue et perceptive pour traverser les différentes zones harmoniques. Enfin, les diagrammes jouent le rôle d'une théorie musicale de substitution pour cet autodidacte, lui procurant une méthode unique d'organisation de la guitare.
All Rights Reserved (C Canadian University Music Society / Société de musique des universités canadiennes, 2005
Ce document est protégé par la loi sur le droit d'auteur. L'utilisation des services d'Érudit (y compris la reproduction) est assujettie à sa politique d'utilisation que vous pouvez consulter en ligne.

https://apropos.erudit.org/fr/usagers/politique-dutilisation/ 

GREENWICH $^{1}$

\section{Andrew Scott}

Although listed in the New Grove Dictionary of Jazz as among the "most important Canadian jazz musicians," Herbert Lawrence "Sonny" Greenwich (b. 1936), who emerged on the Toronto scene in the late 1950s, is not as well known as such contemporaries as guitarist Ed Bickert, alto saxophonist Morris "Moe" Koffman or trombonist/bandleader Rob McConnell (Kernfeld 1988, 91). There is, however, an oral history about the guitarist that speaks to his importance. Interview and documentary research indicates that such major jazz figures as Elvin Jones, Jack DeJohnette, John Handy, Lee Morgan and Wayne Shorter all knew and admired Greenwich, demonstrating confidence in his abilities by hiring him for recordings or live performances. For example, John Handy employed Greenwich for the 1967 "Spirituals to Swing" concert at Carnegie Hall, and both Lee Morgan and Horace Silver (independent of one another) approached Blue Note Records about recording the guitarist. ${ }^{2}$ Greenwich did ultimately record for Blue Note, as a side person on Hank Mobley's 1967 recording Third Season with Lee Morgan, James Spaulding, Cedar Walton, Walter Booker and Billy Higgins (Mobley 1998). Further, Greenwich signed a recording contract with Orrin Keepnews of Riverside Records, and was preparing to make his first album (with Joe Zawinul on piano) when his employment authorization expired and he was forced to return to Canada in 1967..$^{3}$ Immigration issues were a consistent problem for the guitarist. Lacking a permanent work permit that would enable him to enter the United States for purposes of employment, Greenwich was forced to turn down potentially career-altering job offers from Lena Horne and Miles Davis, with whom Greenwich performed at Toronto's Colonial Tavern in December 1969.

1 This essay is an expanded version of a paper originally presented at the University of Guelph Jazz Festival Colloquium on 4 September 2002. The author wishes to thank Dr. James Deaville, Charles Henderson and Marilyn Scott for their editing, Dr. Howard Spring and an anonymous reviewer for their insights into an earlier version of this article, and Jim Clayton and Christy DiFelice for the music engraving. Thanks also to Sonny Greenwich as artist and Barry Elmes as President of Cornerstone Records Inc. for authorizing the use of the musical examples contained within this article, and to Sonny Greenwich for graciously consenting to be interviewed and quoted for this project.

2 Sonny Greenwich, interview with Andrew Scott, 12 July 2002. Hereafter Greenwich, pers. interv. 2002.

3 Joe Zawinul, interview with Andrew Scott, 1 October 2004. 
One of the most intriguing aspects of Greenwich's history is the reputation he holds among fellow jazz guitarists. For example, Phil Upchurch, a guitarist and bassist who enjoyed longstanding musical relationships with George Benson, Donny Hathaway, Otis Rush and The Ramsey Lewis Trio, told me how excited two-time Grammy award winning guitarist Wes Montgomery was after hearing Greenwich "sit in" with his Montgomery Brothers band at New York's Half Note. ${ }^{4}$ According to Upchurch, Montgomery promised to take Greenwich's name to saxophonist John Coltrane who was hoping to add guitar to his band. Similarly, Greenwich recounted that pioneering jazz/rock fusion guitarist Larry Coryell was so intimidated by his skills that he didn't want to perform after hearing Greenwich at the Village Vanguard with Teddy Saunders, Jimmy Garrison and Jack De Johnette (Greenwich, pers. interv. 2002). I suggest that the aforementioned discourse surrounding Greenwich is valuable for two principal reasons. First, it underscores how highly regarded Greenwich was (and is) within the jazz community, and secondly such narratives reveal a story that, until now, has not been examined fully. ${ }^{5}$

This article explores Greenwich's 1994 improvisation "Sonics II" (Greenwich and Bley 1995). Unrehearsed and recorded "live off the floor" in a Montreal studio, "Sonics II" offers a valuable portal into the improvisational style of Greenwich. A second goal of this article is to explore Greenwich's comments about his music and marry them to the transcription. The parallels he draws between his musical style and visual shapes are especially intriguing.

Greenwich was born in Hamilton, Ontario on 1 January 1936, but grew up in the Kensington Market neighborhood of Toronto. His father, Herb, was a railroad porter for Canadian Pacific and a pianist. His piano playing and large record collection were Greenwich's earliest musical influences. "I grew up listening to the records that he had-Earl Hines, Art Tatum-and I still remember them very clearly" (O'Reilly 1979/1981). Greenwich's first professional music job was with The Connie Maynard band in Toronto. A soulful pianist in the style of Wynton Kelly, Maynard was one of Greenwich's earliest supporters. "He's the one that got me started. I was sitting on my porch playing guitar and he drove by. He backed up and asked me if I wanted to play a dance" (Greenwich, pers. interv. 2002). Greenwich played rhythm and blues with Maynard. As he told Ted O'Reilly, longtime program director and disc jockey for Toronto's first jazz radio station CJRT, "We liked jazz, but we could only exist through rhythm and blues. So we played jazz sometimes in a community centre where they gave us this room and people would come in and listen. For a living we played rhythm and blues-I must have played in every bar in Toronto, behind strippers... everything" (O'Reilly 1979/1981). Although Greenwich was making a living playing rhythm and blues, he was frustrated. "I'd come into a jazz club later and when I played I'd be playing

4Phil Upchurch, interview with Andrew Scott, 14 November 2002.

5 As Steven F. Pond $(2003,17)$ points out, classifying only certain writing as "academic" or "scholarly" is clumsy. Accordingly, my comment that Greenwich's story has not been examined "fully" refers largely to the lack of musical analysis on the guitarist and is not meant to detract from the "scholarly" work of Mark Miller, who wrote about Greenwich in Miller (1982, 188-207). 
all these rhythm and blues licks. Finally I decided to just give it all up and play jazz" (O'Reilly 1979/1981).

Greenwich's transition from rhythm and blues to jazz was not easy. "At first it was like walking on a tightrope. I've always heard something different than everyone else. Even when I was still playing traditional songs in the traditional form I'd put different chords to them, get a different sound going. I used to have so much trouble in those days" (Barnes and Gallagher 1975, 4). Greenwich was neither the first nor the last jazz musician to encounter resistance for having a unique musical approach. In this next section I offer one historical example in the career of saxophonist Lester Young.

When Young replaced Coleman Hawkins in Fletcher Henderson's band in 1934, Henderson's band members and wife/manager Leora encouraged Young to model his sound and improvisatory style after the recently departed tenor saxophonist (Schuller 1989, 547). Young never did. He was fired from Henderson's group and replaced by Ben Webster, who would later come to prominence with Count Basie's ensemble in 1936. Although Mark Gridley dedicates a page of his undergraduate text Jazz Styles to exploring such differences between Hawkins and Young as their "tone quality," "rate of vibrato," "swing feeling," "intricacy of solos" and "tunefulness of improvisations" (among other parameters), recordings of both men from the late 1930s reveal differences mainly in their timbre and improvisational style (Gridley 2003, 131). While Hawkins had moved away from the staccato "slap tongue" saxophone technique by the mid-1930s, his playing continued to exhibit a heavier rhythmic feeling than Young's. Secondly, Hawkins and Young's improvisational styles can be contrasted as "vertical" and "horizontal" respectively. While Young's improvisations would not implicitly follow the "changes" of a composition, as Lawrence Gushee points out, Hawkins's improvisations (most notably his 1939 recording of "Body and Soul") find him arpeggiating "vertically" through various triads and four-part chords that are either related to or implied by the harmony of the composition's harmony (Gushee in Porter 1991, 247). To be sure, jazz historiography embraces both styles and approaches. However, I am pointing out the differences between Young and Hawkins's improvisatory styles here to demonstrate that the sonic ideals of an ensemble or a musical scene can impact the careers of jazz musicians.

The difficulties Young encountered in terms of his acceptance into the music community resonate with Greenwich's experience. At the time of Young's entrée into the Henderson orchestra, Hawkins's wide vibrato, muscular tone and harmonically adept improvisatory style enjoyed a certain hegemony in jazz. And when Greenwich appeared on the Toronto jazz scene in 1959, many local guitarists were emulating the American guitarist Jim Hall, whom Greenwich sounds nothing like. "Well the thing that has always happened to me is that I've always had my own style and sound. And so many, many times I've been put down for it. Because I come in, and I'm playing this different thing over these guitarists whose source is Jim Hall. That's happened to me many, many times over the years" (O'Reilly 1979/1981).

Greenwich suggests that his "different musical outlook" was influenced by a thorough study of such non-musical topics as continental philosophy and the 
Vedic Upanishads. "So at the same time as I was doing all of this rhythm and blues and this jazz playing, I was doing all of this studying on top of that. That's sort of why I have a different outlook on things than you usually have with guitar, because I've never been totally involved with the guitar" (O'Reilly 1979/1981). The work of Swiss painter Paul Klee (1879-1940) is among the influences Greenwich cites (Greenwich, pers. interv. 2002). "The solo structures of my playing were based on an interpretation of the work of cubist artist Paul Klee, where I saw the fretboard in diagrams," writes Greenwich in the liner notes to his 1993 release "Standard Idioms" (Greenwich 1993).

I suggest that Greenwich's fretboard diagrams act as a surrogate music theory for the self-taught guitarist and enable him to overcome potential problems that might stem from his lack of formal musical training. According to David Hargreaves, physical strategies used to overcome obstacles on the instrument are the result of sophisticated metacognitive skills. Unlike beginning jazz improvisers, who are perhaps fixated at the sensorimotor phase and are limited in their musical expression by physical or technical problems with their instrument, seasoned jazz musicians employ physical gestures in order to overcome potential problems and achieve desired musical results (Hargreaves 1996). Accordingly, Greenwich's improvisational fluidity and competence can be seen as a result of his ability to encode various musical elements in the body and in bodily processes. For example, instead of thinking of keys, scales or arpeggios, Greenwich uses visual shapes and hand positions - that he has termed "diagrams" and sees as resulting from the work of Klee-to organize the guitar neck. These diagrams inform Greenwich's improvisations, suggesting a framework of pitches that he can delineate, surround or approach through any number of malleable trajectories. "With me it is what the chord looks like," he explains. Picking up his guitar, Greenwich continues, “... like this chord," playing a standard "A-minor 7 add 9" voicing on the top four strings of the guitar (example 1). "I know how to get through that chord," playing example 2 (Greenwich, pers. interv. 2002).

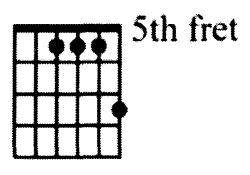

Example 1. Guitar diagram for A-minor 7 add 9

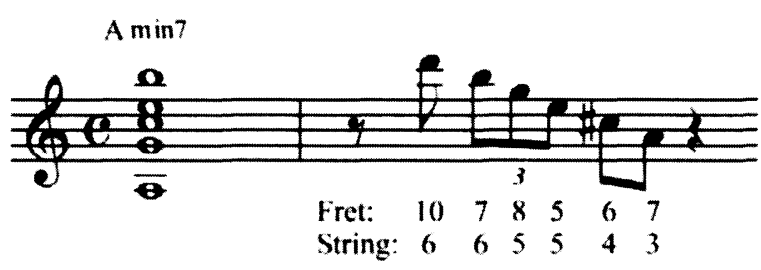

Example 2. "I know how to get through that chord"

The musical phrase that Greenwich plays "over" the "A-minor 7 add 9" voicing demonstrates that individual pitches have less importance to Green- 
wich then how the arc or shape of the musical line relates to his diagram. For example, from a tonal perspective the major third ("C\#") placed on a strong beat (beat three) contradicts the minor character of the "A-minor chord." Greenwich justifies his pitch choice, however, by relating every note of the phrase as either part of, leading to, or within close proximity to his chord diagram. The initial " $D$ " (played with his third finger on the high $E$ string 10th fret) leads to " $B$ " (first finger on high " $E$ " string 7th fret). The next dyad ("G" to "E") is the same harmonic interval (a descending minor third) and is analogous in shape to the first dyad: " $G$ " (third finger " $B$ " string 8th fret) leading to " $E$ " (first finger " $B$ " string 5th fret). While neither the "C\#" nor " $A$ " are found within Greenwich's diagram, it is their close proximity to the diagram-the "C\#" (second finger "G" string 6th fret) is one fret away from a diagram note, the " $A$ " (third finger " $D$ " string 7 th fret) is two frets away-that Greenwich cites to explain his note choice.

In example 1, Greenwich's diagram is "iconic" in that it visually suggests the shape, inflection and contour of various melodies without reference to pitch or note duration. This handy coupling of fretboard diagram to harmonic shape is not, however, always consistent. Rather, Greenwich's diagrams can be viewed as representing a "complex of habits and associations" that trigger mental and musical processes in the guitarist and "enable [him] to compose at high speed" (Treitler 1974, 356). For example, Greenwich uses the diagram presented in example 4 to improvise on what he hears as an "F-major 7" sound (example 3).

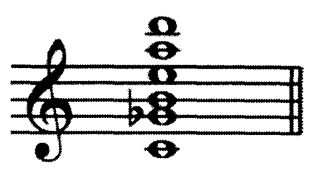

Example 3. What Greenwich "hears" over an F-major 7 tonality

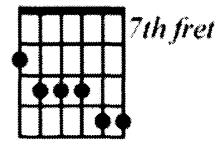

Example 4. What Greenwich "hears" over an F major tonality as guitar diagram

Again, his diagram contradicts tonality. While the diagram contains three of the four notes of an "F-major 7" chord, the absence of a tonic coupled with the presence of such out-of-key notes as " $B$ " natural and most startlingly " $F \#$," suggests polytonality. Greenwich then improvises some melodies he perceives to be borne from this shape (examples 5-7).

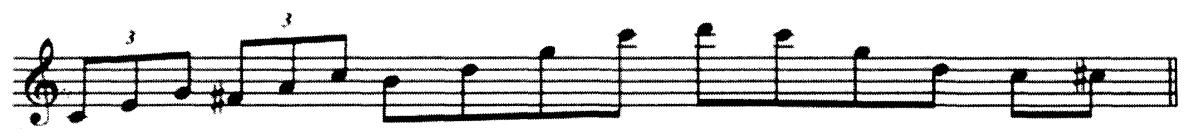

Example 5. Melody 1 that results from example 4 diagram 


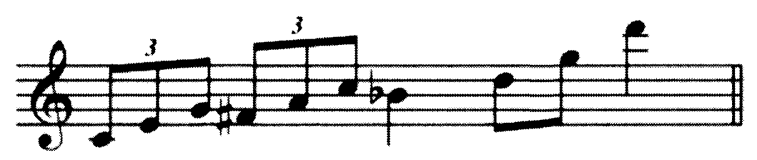

Example 6. Melody 2 from example 4 diagram

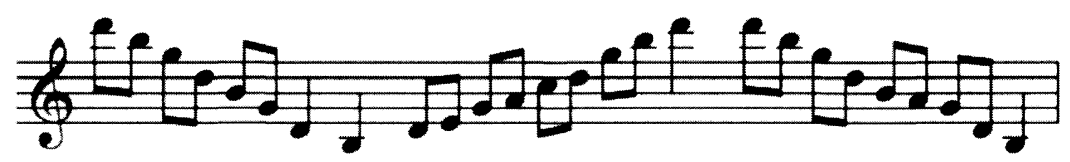

Example 7. Melody 3 from example 4 diagram

In each instance, Greenwich's improvisations contain pitches outside of the

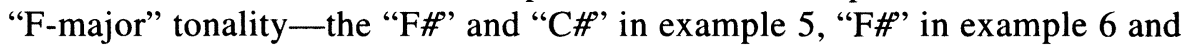
the multiple " $B$ " naturals articulated in example 7. Greenwich again justifies these pitch choices as connected to his diagram. In this instance, however, the diagram not only suggests a framework of pitches for Greenwich to employ, but lead the guitarist to new harmonic trajectories. According to Greenwich, example 4 is the "larger cube" from within which various melodic lines (examples 5-7) can be created. As Greenwich told Ken Waxman $(1978,115)$, diagrams enable him to play "not only the melody, but other melodies suggested by the chord."

In this respect, Greenwich's diagrams are highly flexible. "I'd see the diagram here on the keyboard [fretboard] and I'd see between here and here. So I'd play these diagrams, then I'd change them around and play them the other way," he explains playing melodies he sees as contained within the "larger cube" of the diagram (Greenwich, pers. interv. 2002). The flexibility of Greenwich's diagrams has similarities to the "formulaic" approach of guitarist Charlie Christian. Howard Spring, who has concluded that Christian used guitar chords or shapes (often triadic or "dominant-7" chord voicings) as springboards for his improvisations, notes that Christian's formulas, like Greenwich's diagrams, exhibit a considerable degree of variability in detail (Spring 1980, 3).

Thus far, I have argued that Greenwich uses diagrams in a threefold fashion. First, as a meaningful and highly personal way of discussing his craft, second as a formulaic and perceptual strategy for traversing various harmonic terrains, and third as a method of organizing the guitar neck. In this next section, I analyze my own transcription (appendix) of Greenwich's improvisation "Sonics II". Before beginning, however, I will briefly discuss the relevant musicological literature that mentions formulas, patterns, shapes and/or diagrams.

Although there is no a priori method for jazz analysis, formulaic research is common. The term formula entered the musicological lexicon by way of linguistics. Milman Parry and Albert Lord, through close examination of The Iliad and The Odyssey, argued that because both works were transmitted orally, they are better understood as spontaneous oral creations than written work as discussed in Treitler (1974). Using the still-living tradition of Yugoslavian epic poetry as a 
template, Parry and Lord concluded that oral poetry involves a composing, performing and reciting triumvirate. Parry and Lord were most intrigued by the connection between spontaneous composition and recitation. They asserted that oral poets (or singers) draw from a collection of formulas-defined as a "group of words which is regularly employed under the same metrical conditions to express a given essential idea"- that adhere to the overarching conventions of the poem, while simultaneously adding personalized style, ornamentation or detail (Parry and Lord, in Treitler 1974, 355-56). Leo Treitler, an early music specialist working with medieval plainchant, saw multiple points of intersection between epic poetry and the recitation of pre-pneumatic plainchant. Specifically, he argued that formulas helped constitute the "mechanisms of oral transmission" (Treitler $1974,333)$. Formulas helped the singer make music equally informed by memorization and improvisation.

Perhaps it is not surprising that the study of jazz improvisation, the seemingly mysterious ability to "pick notes out of thin air," was aided by formulaic research (Berliner 1994, 9). Scholars Lawrence Gushee (1981), Howard Spring (1980), Jonathon Finkelman (1997) and Gregory E. Smith (1983) have applied conclusions and concepts culled from formulaic research to jazz musicians Lester Young, Charlie Christian and Bill Evans respectively. In this next section, I use the conclusions of these scholars (and others) to examine Greenwich's improvisatory style.

"Sonics II" is a solo, unaccompanied guitar piece that lasts one minute and forty-four seconds. Greenwich's bright guitar tone is immediately identifiable. His loose right-hand grip, forceful attack and small plectrum executing predominantly up-strokes, is evident throughout. The composition is the leadoff track on the album. Greenwich's introductory phrase is a three-note motif that descends by whole-steps (bars 1-4). The phrase, which I hear as the main theme of the improvisation, can be described as a broken "suspended fourth triad" $(1,4,5)$. Greenwich does not, however, view it as a triad related to a particular key, but rather as both a melodic formula (the sound of which is discussed below) and as part of a diagram he utilizes to traverse the guitar fretboard. Additionally, Greenwich uses the phrase, with some melodic variation, to organize his improvisation. By articulating or alluding to the theme twenty-two times (bars 1-4, 9, 17-20, 25-27, 44-46, 56-59, 70-72), Greenwich employs the formula as the initial "call"- to which a "response" occurs later-lending a conversational aspect to the improvisation. As Samuel Floyd argues, in such call-and-response passages "the instrument performs a kind of sonic mimicry that creates the illusion of speech or narrative conversation" (Floyd 1995, 96). Through discussion with Greenwich, I learned not only that he performed many of these repeated melodic cells on the highest two strings of the guitar ("B" and "E"), but that he "sees" these cells as resulting from the diagram notated in example 1, moving by whole steps down the guitar fretboard. Just as the first melodic cell (bar 1) can be related to the first diagram (example 1) by playing the diagram with his left hand first finger on the ninth fret (as Greenwich does), bars $2-4$ can be related to the diagram located on the seventh, fifth and third frets respectively. The motif thus maintains its physical "look" on the fretboard regardless of pitch selection. Similar to Smith's conclusions that "one of the secrets [of Bill Evans's] rapid decision making in the choice 
of pitches may lie in the nature of arpegggiation," the physical shape of guitar chords influences Greenwich's pitch selection (Smith 1983, 43). While the relationship between diagram and pitch is not uni-directional-as compositional harmony suggests which diagrams Greenwich employs just as the diagrams offer him melodic choices - guitar shapes and physical fingerings, rather than a strict adherence to any chord/scale system of improvisation informs Greenwich's music.

For example, the interval of a perfect fourth-heard in the theme between the first and third notes of the phrase ("Ab" and " $\mathrm{Db}$ " bar 1 , "Gb" and " $\mathrm{Cb}$ " bar 2, "E" and "A" bar 3, "D" and "G" bar 4)—is particularly attractive to Greenwich, who connects this sonic gesture to certain twentieth-century Western Art music composers. While explaining his improvisatory approach to me, Greenwich executed the following phrase over an "E" tonality.

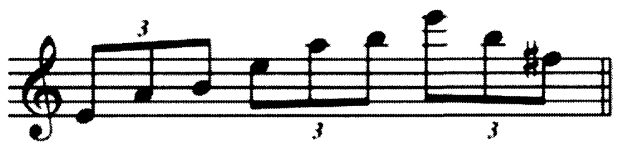

Example 8. Phrase over an "E" tonality

"That sounds like a certain classical style ... like Scriabin," Greenwich states. "So I think that's why Bill Evans asked me what I'm doing" (Greenwich, pers. interv. 2002). Here, Greenwich is referring to the time when he played opposite the late pianist in 1967 as a member of John Handy's group. Intrigued by Greenwich's chords, Evans approached the guitarist with questions. "What he wanted to discuss were my ideas on composition" (Greenwich 1993). I mention to Greenwich that Evans shared his affinity for fourths, citing Evans's use of quartal voicings on Miles Davis's 1959 recording So What (Davis 1959). Greenwich picks up on my terminology. "That's what I'm doing. Basically, the chords I'm playing behind him [Handy] are fourths. I figured out how they all fit together from major to minor" (Greenwich, pers. interv. 2002). This point, which is central to Greenwich's approach, can be developed in a twofold manner. As demonstrated earlier by the "A-major" line that Greenwich improvised "over" an "A-minor 7 add 9 chord," Greenwich rarely thinks in terms of major or minor tonalities. For example, the quartal or suspended-fourth triadic line that Greenwich improvised in example 8 lacks scale degree three and therefore does not clearly delineate a major or minor sound. As a result, harmonic ambiguity over an " $E$ " tonality is achieved.

There is, however, another explanation for Greenwich's repeated use of fourths. The predominant interval of standard guitar tuning ("E," "A," "D," "G," "B," "E") is the perfect fourth. With the exception of the "G" to " $B$ " interval that separates the instrument's fourth and fifth strings, the open guitar strings are built in fourths. Therefore, while quartal voicings and lines are difficult to execute on piano as they require a larger hand span then closevoiced tertian chords, fourth voicings are relatively easy on the guitar as a quartal interval is achieved by laying a single finger across adjacent strings on the same fret (except between the " $G$ " and " $B$ " strings). Accordingly for 
Greenwich, who organizes the guitar by hand position, shapes and diagrams, the connection to fourths is as much visual as aural.

Although unusual, Greenwich's reliance on physical shapes as a method of improvisation is not sui generis. As Harris Berger has argued, rock and heavy metal musicians often relate physically to the music they play (Berger 1999, 194). For example, harmony is understood from the root-fifth interval shape (the so-called "power fifth") and improvising is learned through experimentation with the box pattern/shape of the pentatonic scale (examples 9 and 10).

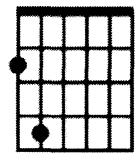

Example 9.

The "Power Fifth"

guitar shape

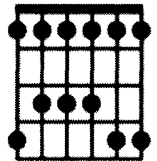

Example 10.

Guitar pattern for major pentatonic scale

Baily and Driver present arguments similar to those of Berger (Baily 1985; Baily and Driver 1992). Indexing musical creativity to "finding new ways to move on the instrument," Baily and Driver argue "the spatio-motor mode should be regarded as a legitimate and commonly used mode of musical thought," pointing out that rock guitarists remember and execute music "not solely as aural patterns, but as sequences of movements, and that the music is therefore represented cognitively in terms of movement patterns which have visual, kinesthetic, tactile, as well as auditory repercussions" (Baily and Driver $1992,59,62)$. Physical relationships are not, of course, limited to rock musicians. Such jazz musicians as Christian and Evans, as I have articulated earlier, also rely on embodied fingering patterns or an instrument's physical layout to aid improvisation.

An examination of bars 12-13 yields another clear example of Greenwich's reliance on chordal shapes or diagrams. Here, Greenwich makes a I to IV move, arpeggiating up a close voiced "G-major 7" chord followed by a "C-major 7." Through conversation with Greenwich, I learned that pitch selection was again dictated by the diagram of the chord (Greenwich, pers. interv. 2002). Because of the symmetrical nature of the guitar, Greenwich uses the identical fingering and chord shape for both musical passages, simply re-constituting the diagram five frets higher. With the exception of the major sixth ("E" over the "G-major 7" chord and "A" over "C-major"), all notes fit perfectly into the "major-7" chord voicing. The close proximity of scale degree six to scale degree five-the latter note is contained within the diagram - allows its presence in the musical line.

Tertian triads offer Greenwich a threefold improvisational strategy. First, Greenwich uses major triads to ascend register rapidly. Bars 29 and 37 clearly illustrate this point as Greenwich uses only six notes to traverse an octave. Secondly, Greenwich uses parallel triadic shapes to maneuver across the fretboard. Bars 12, 13, 29 and 37 demonstrate Greenwich using parallel chords or triads to ascend harmonically—often cycling through key centres separated 
by the interval of a perfect fourth. Bars 61-67 demonstrate another use of the triadic form. Here, Greenwich simply lays his finger across the guitar's " $D$," "G" and "B" strings. The result is an arpeggiated second inversion "major triad" that Greenwich moves chromatically by simply maintaining the physical shape of the chord and shifting his left hand towards his body a single fret at a time ("D-major" in bar 61, "Eb-major" in bar 62, "E-major" in bar 63, "F-major" in bar 64, "Gb-major" in bar 65, "G," "Ab," "A" and "Bb-major" triads and the first two notes of a "B-major" triad over bars 66-68). Once again, Greenwich's sonic gesture does not adhere to any overarching tonality or key centre, but rather is informed by a single diagram.

Bars 61-67 also exhibit the most intense chromaticism of the performance, a hallmark of Greenwich's style. And while an examination of his note choice reveals that Greenwich uses ascending inverted major triads to manoeuvre through these bars, Greenwich is once again not thinking of triadic harmony while improvising. Rather, Greenwich hears these chromatic episodes as building the necessary tension for an effective harmonic release heard here in bar 68 as the "E" to "A" double-stop.

Greenwich often builds harmonic tension by "sidestepping" chromatically between chord changes. "I'd be playing across the neck and whatever chord came up I'd change it to what that chord was. So these chords could be going by and I'd be doing those figures and I'd change it to the chord that came up then. So I was on that note that came up. Then I could go from there to something else" (Greenwich, pers. interv. 2002). In addition to "seeing" how chord diagrams connect together visually, Greenwich is clearly noting that he portends or hears ahead of where he is playing to the next harmonic change. He aims his lines at a pre-ordained target pitch (a note he sees as contained within a chord diagram) and proceeds along any number of trajectories (chromatic, scalar, appoggiatura). The key for Greenwich is that he is "on that note when it comes up." In other words, how he arrives at the target note is not as important as the arrival itself. "In a song I'll go out of one pattern, and come back to another pattern," Greenwich elaborates (pers. interv 2002). Arguably, it is this sidestepping and resolution that not only imbues a sense of tension and release into his improvisations, but also gives his playing a propulsive sense of swing. Greenwich's 2001 improvisation on Lionel Bart's "Where is Love" offers a good example of this sort of forward motion and resolution during the composition's "turnaround" back to the tonic key of "Bbmajor" (example 11) (Greenwich 2001).

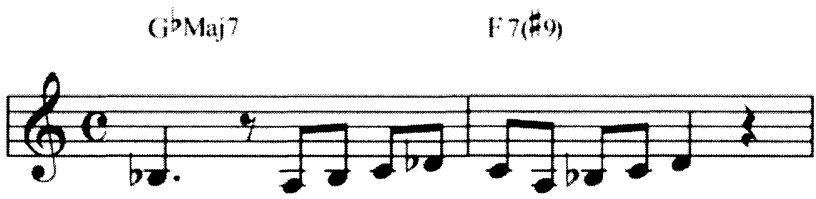

Example 11. "Where is Love," guitar improvisation as played by Sonny Greenwich (2001)

Through a combination of note choice and phrasing, Greenwich can be heard as playing ahead to the next harmonic change-in the second half of the first bar ("Gb-major 7"), Greenwich's note choice adheres better to the "F-dominant 
7 \#9" than the "Gb-major 7." While this phrase is not predominantly rhythmic, by delineating scales-tones $3,4,5$ and flat 6 , before resolving into the natural fifth ("C") of "F-dominant 7" on the first beat of the next bar, Greenwich "pulls" the listener toward the next harmonic change and imbues a sense of swing into the performance.

I am aware that much of the sort of musical analysis presented here, with pitch names and formalistic discussions of structure and tonal organization, has fallen under considerable scrutiny when applied to jazz and other African-American, in this case African-Canadian, music making practices. For example, central to the criticism leveled at such jazz scholars as Gunther Schuller and André Hodeir, both of whom were trained in methodologies utilized primarily in the study of Western Art music, is that harmony and melody, and theoretical discussions thereof have been elevated in their work to a privileged position (Schuller 1989; Hodeir 1980). As Krin Gabbard argues, although "a jazz musicologist influenced by Hodeir may not overtly argue that Ellington is the equal of Brahms, his use of analytical methods designed for Brahms makes the argument all the same" (Gabbard 1995, 15). In other words, it is argued that the principles, tools and language used in discussions of Western Art music to explore melodic development, logical phraseology and teleological narrative do not necessarily have a commensurate place in analysis of African-American music. These aforementioned aesthetics, not to mention the competency one must possess in order to maneuver freely within this discourse, are both socially and politically mediated, and historically indexed to a cultural group removed from African-American culture. The frequent result is that scholarly explorations of African-American music that focus primarily on harmony and fail to address the social and participatory aspects so central to that culture's music making processes leave a great deal in need of unpacking. Accordingly, my final section offers an alternate reading of Greenwich's improvisatory style.

Clearly, there are aspects of Greenwich's performance that have escaped mention in my article thus far as they cannot be properly conveyed by musical notation nor explained fully through musical analysis. Four examples include his inflected notes (often bent sharp and heard in bars 54, 59, 71, 72), his "muffled" notes (bars $5,67,73,78,82$ ), his propulsive rhythmic drive that is not tied to the overarching rhythmic grid of the improvisation (bars 19,27,43) and his distortions of timbre-Greenwich's concluding power chord in bar 83 and "double-stops" in bars 43 and 68 clearly challenge normative conceptions of jazz guitar tone. While conventional musical analysis offers few ways of discussing these four musical gestures-other than missing the point entirely and hearing these qualities as imperfect intonation, sloppy technique, bad time and an idiomatically inappropriate sound respectively - these qualities are both central to Greenwich's style and contribute to the meaningfulness (for me) of his performances. All result from what I term Greenwich's "loose" manner of playing the instrument. ${ }^{6} \mathrm{He}$ achieves this loose aesthetic three ways: (1) his use of a thin plectrum, (2) his "light" right-hand plectrum grip and (3) his frequent left-hand shifts across the guitar's

6The idea of this "loose" style of playing came out of a discussion with Rob van der Bliek (28 February 2005). 
fretboard. These three performance practices contribute to a rhythmic style too fluid to be articulated by four-square phrase markings, a sonic style that includes the ringing of "open" guitar strings and a melodic style that contains "bent" notes and "muffled" pitches, the later of which often occur when his fingers accidentally fall upon various pitches during his frequent left-hand shifts. Further, each of these performance practices can be related to the blues.

Similar to Ornette Coleman, Albert Ayler and John Coltrane, all musicians who performed so-called "free jazz" at various times, Greenwich began his career playing rhythm and blues. By his own account, these early musical experiences have remained important to him. "In retrospect I think that what I did was take the rhythm aspect from rhythm and blues and bring that into my jazz playing," Greenwich recalled in a 2004 interview. ${ }^{7}$ Through further discussion with Greenwich, I interpret his comments to mean that he wanted to imbue his jazz playing with the sort of energy and drive he experienced performing with such Toronto rhythm and blues bands as those led by Connie Maynard and Donnie Carrington (Greenwich, pers. interv. 2004). Accordingly, I hear Greenwich's rhythmic drive, microtonally inflected notes and his "sliding on guitar strings" as indexed to both the blues tradition, and to a set of musical aesthetics reified by the musical community in which he came up as a player (Oliver 2005). Further, Greenwich's distorted timbre and audibly inflected notes that are both "out of tune" and "out of time," to cite Charles Keil's "participatory discrepancy" theory, can be indexed to a blues topology in which instrumental squawks and growls, bent pitches and a general vocalized instrumental timbre are celebrated (Keil 1994, 96).

Whether viewed as signifying on the blues tradition, a method for traversing complex harmonic terrains or a way of organizing the guitar fretboard, chordal diagrams offer Greenwich a flexible musical strategy. Like Treitler's plainchant singer, Greenwich "does not make sketches, he does not consult a catalogue of formulas and deliberate about which ones he will string together" (Treitler 1974, 346). Instead, visual shapes - that for Greenwich are reminiscent of Klee's paintings - form an aggregate of malleable improvisatory ideas.

7 Sonny Greenwich, interview with Andrew Scott, 12 December 2004. Hereafter Greenwich, pers. interv. 2004. 
Appendix. Sonny Greenwich's improvised composition "Sonics II" (transcription)

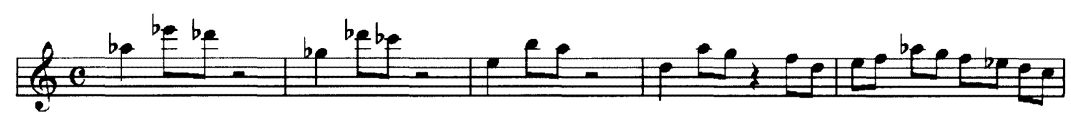

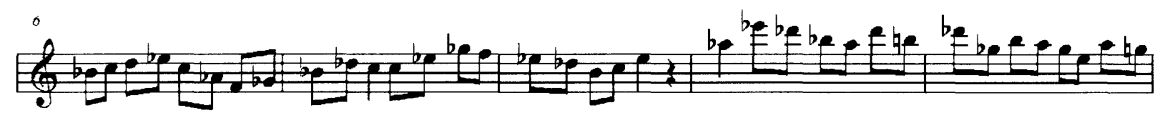

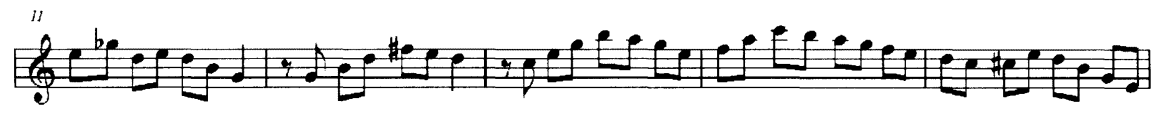

(2)

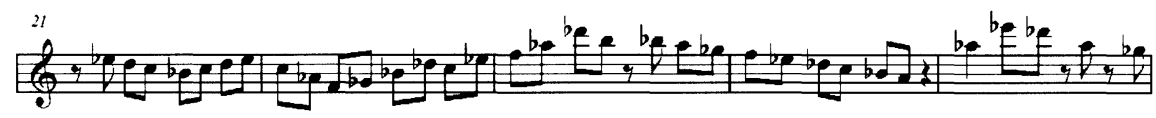

2.

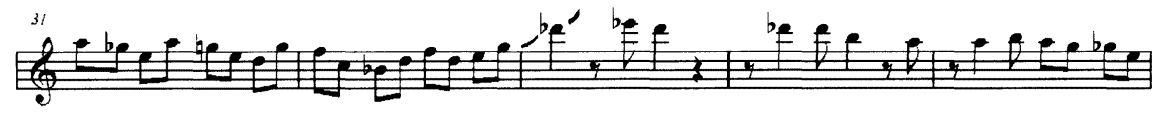

tomenter 
Appendix - cont'd

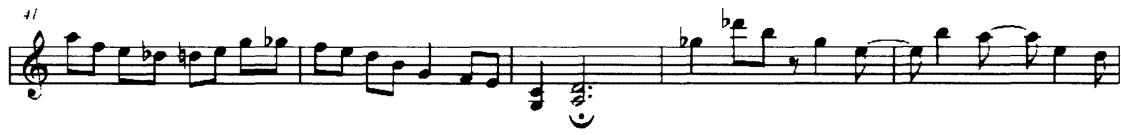
Fith

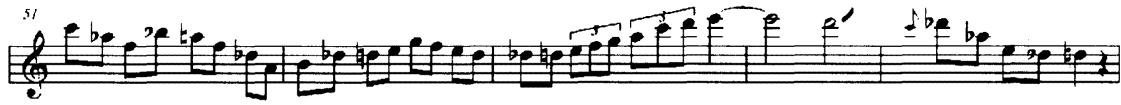

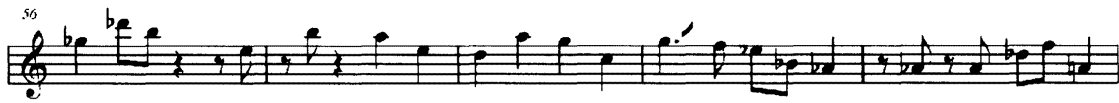
1

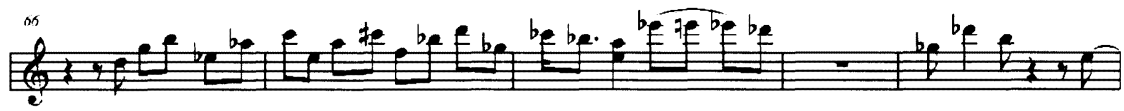
F) F

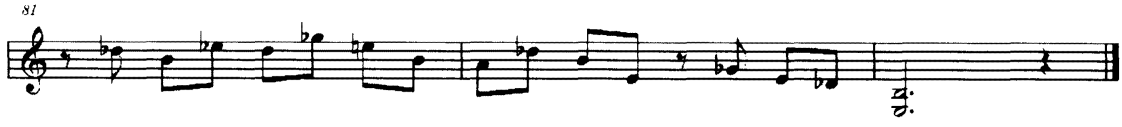




\section{REFERENCE LIST}

Baily, John. 1985. "Music Structure and Human Movement." In Musical Structure and Cognition, eds. Peter Howell, Ian Cross and Robert West, 237-58. London: Academic Press.

Baily, John, and Peter Driver. 1992. "Spatio-Motor Thinking in Playing Folk Blues Guitar." World of Music 34, no. 3: 57-71.

Barnes, Lilly, and Greg Gallagher. 1975. "Sonny Greenwich, Don Thompson: Love of Jazz Dispels Contrasts between Musician-Composers." The Music Scene (May-June): 4-5.

Berger, Harris. 1999. Metal, Rock, and Jazz: Perception and the Phenomenology of Musical Experience. Hanover, NH: Wesleyan University Press.

Berliner, Paul. 1994. Thinking in Jazz: The Infinite Art of Improvisation.

Chicago: University of Chicago Press.

Davis, Miles. 1959. Kind of Blue. Columbia 469440-2.

Finkelman, Jonathon. 1997. "Charlie Christian and the Role of Formulas in Jazz Improvisation." Jazzforschung/Jazz Research 29: 159-88.

Floyd, Samuel A. 1995. The Power of Black Music: Interpreting its History from Africa to the United States. Oxford: Oxford University Press.

Gabbard, Krin. 1995. "Introduction: The Jazz Canon and Its Consequences."

In Jazz Among the Discources, ed. Krin Gabbard, 1-28. Durham and

London: Duke University Press.

Greenwich, Sonny. 1993. Standard Idioms. Kleo Records Kleo 1-CD. 2001. Fragments of a Memory. Cornerstone Records Inc. CRST CD 116.

Greenwich, Sonny, and Paul Bley. 1995. Outside In. JustinTime Records Just 69-2.

Gridley, Mark. 2003. Jazz Styles: History and Analysis. 8th ed. Upper Saddle River, NJ: Prentice Hall.

Gushee, Lawrence. 1981. "Lester Young's Shoeshine Boy," In International Musicological Society, Report of the Twelfth Congress, Berkley, 1977, ed. Daniel Heartz and Bonnie Wade, 151-69. Kassel: Barenreiter.

Hargreaves, David. 1996. "The Development of Artists and Musical Competence." In Musical Beginnings: Origins and Development of Musical Competence, eds. Irène Deliege and John Sloboda, 145-70. New York: Oxford University Press.

Hodeir, André. 1980. Jazz: Its Evolution and Essence. Rev. ed. New York: Grove Press. (Orig. pub. as Hommes et problèmes du jazz, Paris: Flammarion, 1954; first Engl. ed. New York: Grove Press, 1956.)

Keil, Charles. 1994. "Participatory Discrepancies and the Power of Music." In Music Grooves: Essays and Dialogues, Keil Charles and Steven Feld, chap. 3. Chicago: University of Chicago Press.

Kernfeld, Barry. 1988. "Greenwich, Sonny [Greenwich, Herbert Lawrence]."

Grove Music Online, ed. L. Macy. http://80-www.grovemusic.com. ezproxy.library.yorku.ca (accessed 21 March 2005).

Miller, Mark. 1982. Jazz in Canada: Fourteen Lives. Toronto: Nightwood Editions. 
Mobley, Hank. 1998. Third Season, Blue Note CD 97506.

Oliver, Paul. "Origins: Blues." Grove Music Online, ed. L. Macy. http://80www.grovemusic.com.exproxy.library.yorku.ca (accessed 9 February 2005).

O'Reilly, Ted. 1979/1981. Radio interviews with Sonny Greenwich, CJRTFM, 29 August 1979 and 25 February 1981.

Pond, Steven F. 2003. "Jamming the Reception: Ken Burns. Jazz, and the Problem of 'America's Music'." Notes: Quarterly Journal of the Music Library Association 60, no. 1 (September): 11-45.

Porter, Lewis, ed. 1991. A Lester Young Reader. Washington: Smithsonian Institution Press.

Schuller, Gunther. 1989. The Swing Era: The Development of Jazz 1930-1945. New York: Oxford University Press.

Smith, Gregory Eugene. 1983. "Homer, Gregory, and Bill Evans? The Theory of Formulaic Composition in the Context of Jazz Piano Improvisations." PhD diss., Harvard University.

Spring, Howard Allen. 1980. "The Improvisational Style of Charlie Christian." Master's thesis, York University.

Treitler, Leo. 1974, "Homer and Gregory: The Transmission of Epic Poetry and Plainchant." Musical Quarterly 40, no. 3 (July): 333-72.

Waxman, Ken. 1978. "Sonny Greenwich Keeps His Secrets." Saturday Night (November): 112-19.

\begin{abstract}
In this article, the author examines the improvisatory style of jazz musician Herbert Lawrence "Sonny" Greenwich. While numerous extra-musical sources inform the guitarist's performances, the cubist paintings of Paul Klee are particularly meaningful. Through transcription, analysis and interview, the author demonstrates that fretboard "diagrams"-which Greenwich suggests originate from Klee-act in a threefold manner. First, they afford Greenwich a personal way of discussing his craft, second they offer a formulaic and perceptual strategy for traversing various harmonic terrains and third these diagrams act as a surrogate music theory for the self-taught musician, affording him a unique method of organizing the guitar.
\end{abstract}

\title{
Résumé
}

L'auteur se penche sur le style d'improvisation du musicien de jazz Herbert Lawrence "Sonny » Greenwich. Si de nombreuses sources extra-musicales nous renseignent sur les prestations du guitariste, les tableaux cubistes de Paul Klee s'avèrent particulièrement significatifs. À l'aide de transcriptions, d'analyses et d'entrevues, l'auteur démontre que les « diagrammes » des positions sur le manche - qui proviendraient de Klee, selon Greenwich - jouent trois rôles. D'abord, ils fournissent à Greenwich une manière personnelle d'approcher son art. Ensuite, ils offrent une stratégie convenue et perceptive pour 
traverser les différentes zones harmoniques. Enfin, les diagrammes jouent le rôle d'une théorie musicale de substitution pour cet autodidacte, lui procurant une méthode unique d'organisation de la guitare. 